\title{
USULAN PERBAIKANUNTUK MENINGKATKAN PRODUKTIVITAS FILLINGPLANT DENGAN PENDEKATAN LEAN MANUFACTURING PADA PT SMART TbK SURABAYA
}

\author{
Darminto Pujotomo*), Dian Novia Rusanti*) \\ Program Studi Teknik Industri, Fakultas Teknik, Universitas Diponegoro \\ J. Prof. H. Soedarto, SH. Semarang 50239 \\ Telp. (024) 7460052
}

\begin{abstract}
Abstrak
Dalam industri manufaktur, produktivitas merupakan kemampuan perusahaan untuk mengoptimalkan output dari input yang digunakan. Output yang dihasilkan harus dapat memenuhi demand konsumen. PT Smart Tbk Surabaya merupakan salah satu industri manufaktur yang bergerak dalam produksi pengolah minyak kelapa sawit. Dalam proses produksinya terjadi ketidakseimbangan output produksi dengan demand konsumen yang harus dipenuhi. Hal tersebut terjadi karena adanya waste selama proses filling. Permasalahan ini diselesaikan dengan pendekatan Lean Manufacturing dengan memberikan usulan improvement pada proses filling dengan menggunakan metode Line Balancing. Value stream mapping digunakan untuk mengidentifikasi waste yang terjadi selama proses filling berlangsung. Tools yang digunakan dalam lean manufacturing dan line balancing ini digunakan untuk mereduksi cycle time. Berdasarkan hasil analisis didapatkan empat usulan improvement yaitu perbaikan alur proses filling, penggabungan operasi kerja plugging dan capping, continuous flow dengan line balancing dan redesain layout. Usulan improvement tersebut dapat menekan tingkat defect, mengurangi total operation time menjadi 188,55 detik/batch, meningkatkan efisiensi lini menjadi 79,83\% dan menurunkan delay time menjadi $23 \%$.
\end{abstract}

Kata Kunci: produktivitas; waste; lean manufacturing; value stream mapping; line balancing

\begin{abstract}
Productivity is the company's ability to optimize output from all input that they use to production. The output they produce must fulfill the customer demand. PT Smart Tbk Surabaya is one of the private manufacturing industries which are existed in the processing of palm oil. There are unbalance condition during processing the product. The output of the production is different from the customer demand. It happened because there are some wastes during the filling process. This research is focus on solving the problem by using Lean Manufacturing and creating the improvement in filling proces by using line balancing method. The purpose of value stream mapping is to identify waste during filling process. Tools of lean manufacturing and line balancing are used to reducetion the cycle time in a palm oil production. Based on the analysis, there will be four improvements. They are improvement the sequence of filling process; combine the operation of plugging and capping, continuous flow by line balancing and layout redesign. This improvement can reduce the defect rate, the number of operation time up to 188.55 second/batch, increase the line efficiency to be $79.83 \%$ and decrease the delay time to be $23 \%$.
\end{abstract}

Keyword: productivity; waste; lean manufacturing; value stream mapping; line balancing

\section{Pendahuluan}

Dalam rangka meningkatkan kualitas produk dan pelayanan terhadap konsumen sebaiknya perusahaan memikirkan cara untuk meningkatkan produktivitas dengan tetap memperhatikan kualitas

\footnotetext{
${ }^{*}$ Penulis Korespondensi.

email: darminto_pujotomo@yahoo.com, diannoviaar@gmail.com
}

yang baik. Hal ini penting karena peningkatan produktivitas berbanding lurus dengan peningkatan keuntungan perusahaan tanpa perlu menaikkan harga jual produknya. Dengan demikian permintaan konsumen dapat terpenuhi dengan baik.

PT Smart Tbk merupakan salah satu industri manufaktur yang bergerak dalam produksi pengolah minyak kelapa sawit. Produk yang dihasilkan adalah minyak goreng dan margarine. Dalam melakukan kegiatan produksinya PT Smart Tbk tidak lepas dari 

dilakukan. Tujuan akhir pada line balancing adalah memaksimasi kecepatan di tiap stasiun kerja sehingga dicapai efisiensi kerja yang tinggi di tiap stasiun.

Ada beberapa istilah yang lazim digunakan dalam line balancing. Berikut adalah istilah-istilah yang dimaksud (Baroto, 2002):

1. Precedence diagram

Precedence diagram digunakan sebelum melangkah pada penyelesaian menggunakan metode keseimbangan lintasan.

2. Assemble Product

Assemble Product adalah produk yang melewati urutan work station dimana, setiap work station memberkan proses tertentu hingga selesai menjadi produk akhir pada perakitan akhir.

3. Waktu menunggu (Idle Time)

Dimana operator atau pekerja menunggu untuk melakukan proses kerja ataupun kegiatan operasi yang selanjutnya akan dikerjakan. Selisih atau perbedaan antara Cycle time (CT) dan Stasiun Time (ST), atau CT dikurangi Stasiun Time (ST).

$$
\text { Idle Time }=n \cdot W_{S}-\sum_{i=1}^{n} W_{i}
$$

Keterangan:

$\mathrm{n} \quad=$ Jumlah stasiun kerja.

Ws = Waktu stasiun kerja terbesar.

$\mathrm{Wi}=$ Waktu sebenarnya pada stasiun kerja.

$\mathrm{i}=1,2,3, \ldots, \mathrm{n}$.

4. Keseimbangan Waktu Senggang (Balance Delay) Balance delay merupakan ukuran dari ketidakefisienan lintasan yang dihasilkan dari waktu mengganggur sebenarnya yang disebabkan karena pengalokasian yang kurang sempurna diantara stasiun-stasiun kerja. Balance delay dapat dirumuskan sebagai berikut:

$$
D=\frac{n C-\sum t_{i}}{\left(n t_{i}\right)} \times 100 \%
$$

Keterangan:

$\mathrm{D}=$ Balance delay $(\%)$

$\mathrm{C}=$ Waktu siklus.

$\mathrm{N}=$ Jumlah stasiun kerja.

$\sum \mathrm{ti}=$ Jumlah semua waktu operasi.

ti $=$ Waktu operasi.

5. Line efficiency merupakan rasio dari total waktu stasiun kerja dibagi dengan siklus dikalikan jumlah stasiun kerja atau jumlah efisiensi stasiun kerja dibagi jumlah stasiun kerja.

$$
\text { Line Efficiency }=\frac{\sum_{i=1}^{\mathrm{k}} \mathrm{STi}}{(K)(C T)} \times 100
$$

Keterangan:

Sti = Waktu stasiun kerja dari ke-i.

$\mathrm{K}$ = Jumlah stasiun kerja.

CT $=$ Waktu siklus

6. Smoothes index (SI) adalah suatu indeks yang menunjukkan kelancaran relatif dari penyeimbangan lini perakitan tertentu.

Jurnal Teknik Industri, Vol. X, No. 2, Mei 2015

$$
S I=\sqrt{\sum_{i=1}^{K}\left(S T i_{\text {maks }}-S T i\right)^{2}}
$$

Keterangan:

$\mathrm{ST}=$ Maksimum waktu di stasiun

$\mathrm{Sti}=$ Waktu stasiun di stasiun kerja ke-i.

\section{Metodologi Penelitian}

Langkah awal dalam penelitian ini adalah pedekatan Lean manufacturing melalui tahapan yaitu value stream mapping, pengukuran waste, identifikasi akar penyebab dengan fishbone diagram dan memberikan usulan perbaikan. Berikut penjelasannya.

1. Identifikasi Waste dengan VSM

Pada tahap ini dilakukan identifikasi aliran material selama proses filling berlangsung, aktivitas sepanjang value stream, cycle time proses filling, dan kebutuhan man power pada masing-masing aktivitas,

2. Pengukuran Waste

Pengukuran waste dilakukan dengan menggunakan dua tools yaitu P-Chart untuk pengukuran waste defect dan diagram pareto untuk mengetahui waste paling utama berdasarkan peluang banyaknya kejadian.

3. Analisis Akar Penyebab Waste

Analisis ini dilakukan dengan menggunakan diagram fishbone untuk mengetahui akar penyebab waste yang paling utama

4. Usulan Perbaikan dengan Lean Tools

Usulan perbaikan yang diberikan berdasarkan kasus yang dihadapi yaitu dengan menggunakan Line balancing dan Redesain layout. Usulan perbaikan ini diharapkan dapat menjadi improvement yang relevan.

\section{VSM: CURRENT STATE MAP}

Value Stream Mapping (VSM) menggambarkan secara keseluruhan aktivitas dalam proses filling. Dari penggambaran VSM ini dapat memberikan penjelasan mengenai aliran fisik, informasi, material dalam proses filling. Hasil VSM dapat dilihat pada Lampiran 1.

Dalam aliran material VSM tersebut ditemukan beberapa pemborosan seperti yang terlihat pada gambar. Diantaranya adanya waiting, unnecessary motion, dan defect. Adanya pemborosan ini menyebabkan proses filling pada kemasanJerigentidak berjalan dengan lancar. Adanya waste waiting disebabkan karena terjadinya penumpukan work in proceess (WIP). Penumpukan WIP ini dapat diketahui dari jumlah jerigen yang menunggu untuk masuk pada proses selanjutnya. Adanya penumpukan WIP ini dikenal dengan istilah bottleneck. Bottleneck merupakan aktivitas pemborosan yang terjadi akibat operasi selanjutnya menghasilkan output yang lebih kecil dari operasi sebelumnya. Aktivitas bottleneck ini terjadi pada Operasi kedua yaitu operasi labelling. Hal ini dapat dilihat dari output standart yang dihasilkan dari 
masing-masing operasi tersebut. Pada operasi kedua, jumlah output standart yang dihasilkan lebih kecil daripada operasi pertama sehingga dapat menyebabkan penumpukan material yang akan dikerjakan. Jumlah penumpukan WIP yang terjadi adalah sebanyak 3279 unit. Selain itu, adanya pemborosan defect juga menimbulkan proses filling terganggu. Produk defect yang dihasilkan dalam proses filling ini menyebabkan harus dilakukannya rework oleh operator. Akibat yang berkelanjutan dari pemborosan ini adalah operator memiliki kerja tambahan untuk dapat melakukan rework terhadap produk defect sehingga membutuhkan waktu yang lebih lama dari produk yang seharusnya.

\section{Pengukuran Waste \\ P-CHART}

Dari data defect yang yang diambil melalui pengamatan sebanyak $31 \mathrm{kali}$, total ukuran sampel adalah 155.438 unit dan banyak produk defect sebesar 6710. Berdasarkan data tersebut, maka ratarata jumlah defect per hari sebesar 216 unit. Jumlah produk defect ini mencapai angka 4,4\% dari jumlah produk yang dihasilkan.Perhitungan P-Chart ini dilakukan untuk mengetahui variasi proses dengan menunjukkan proporsi cacat secara keseluruhan. Hal ini dapat diketahui dari besarnya nilai batas pengendali atas atau UCL dan batas pengendali bawah atau LCL melalui perhitungan. Perhitungan nilai UCL dan LCL dapat diliat pada tabel di bawah ini.

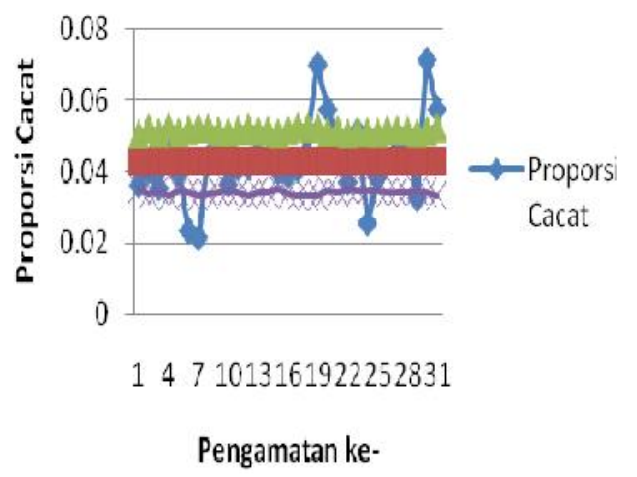

Gambar 1. P-Chart Waste Defect

Berdasarkan P-Chart di atas, terlihat bahwa masih ada nilai defect yang berada di luar batas kendali atas dan batas kendali bawah sehingga masih perlu dilakukan tinjauan ulang dan perbaikan proses untuk mengurangi defect produk.

\section{Diagram Pareto}

1. Waiting

Faktor-faktor waiting yang terjadi adalah terjadinya penumpukan barang setengah jadi (WIP) selama proses filling yang menyebabkan bottleneck. Adanya bottleneck inilah yang menjadi indikator waste waiting yang digunakan dalam perhitungan.

Tabel 1. Penumpukan WIP

\begin{tabular}{lc}
\hline \multicolumn{1}{c}{ Operasi ke- } & $\begin{array}{c}\text { Penumpukan } \\
\text { WIP }\end{array}$ \\
\hline Operasi 2 (Labelling) & 1524 unit \\
Operasi 5 (Capping Luar) & 1755 unit \\
Jumlah WIP & 3279 unit \\
\hline
\end{tabular}

$$
\begin{aligned}
\text { Delay Time }(\mathrm{DT}) & =59,71+30,20 \\
& =89,92 \text { detik }
\end{aligned}
$$

Persentase Delay Time (\% DT)

$=\frac{D T}{O C T} \times 100 \%$

$=\frac{89,92}{222,66} \times 100 \%$

$=40,38 \%$

2. Unneccessary Motion

Waste motion dapat diidentifikasi dari perbandingan persentase aktivitas VA dengan NVA. Perhitungan unneccessarry motion ditunjukkan pada tabel berikut.

Tabel 2. Motion Idle

\begin{tabular}{cc}
\hline Motion Idle & $10,05 \mathrm{detik} / \mathrm{batch}$ \\
(NVA) & $1,31 \mathrm{detik} / \mathrm{unit}$ \\
Total Produk & $5015 \mathrm{unit}$ \\
Cycle Time & $9,35 \mathrm{detik} / \mathrm{unit}$ \\
Produk yang & $1,31 \times 5015$ \\
hilang karena & 9,35 \\
motion & $=704$ unit \\
\hline
\end{tabular}

3. Defect

Defect yang terjadi pada proses filling diketahui pada aktifitas finishing. Inspeksi dilakukan secara $100 \%$ terhadap produk akhir yang telah selesai dalam proses filling. Ketika proses inspeksi diketahui beberapa defect yang terjadi, yaitu:
a. Jerigen rusak
b. Eiket basah
c. Capping tidak presisi

Prinsip pareto menyatakan bahwa $80 \%$ dari masalah berasal dari 20\% dari penyebab (Joshua, dkk., 2014). Berdasarkan hasil yang ditunjukkan oleh pareto chart, dapat diketahui bahwa waste utama yang terjadi pada proses filling adalah waiting dengan persentase sebesar 78,09\%. Waste berikutnya adalah waste motion dengan persentase sebesar $16,77 \%$ dan terakhir adalah waste defect dengan persentase 5,14\%.

\section{Akar Penyebab Waste}

Berdasarkan hasil dari identifikasi waste yang telah dilakukan pada tahap sebelumnya, waste terbesar adalah waste waiting dengan persentase kejadian sebesar 78,09\%. Selanjutnya dilakukan identifikasi akar-akar penyebab masalah dengan 
menggunakan bantuan tools fishbone diagram.Penentukan akar penyebab yang akan ditampilkan dalam fishbone diagram dilakukan berdasarkan faktor material, method, man, machine, dan environment. Sedangkan untuk mendukung ketelitian akar penyebab dari kelima faktor di atas, dilakuakan analisis 5 whys.

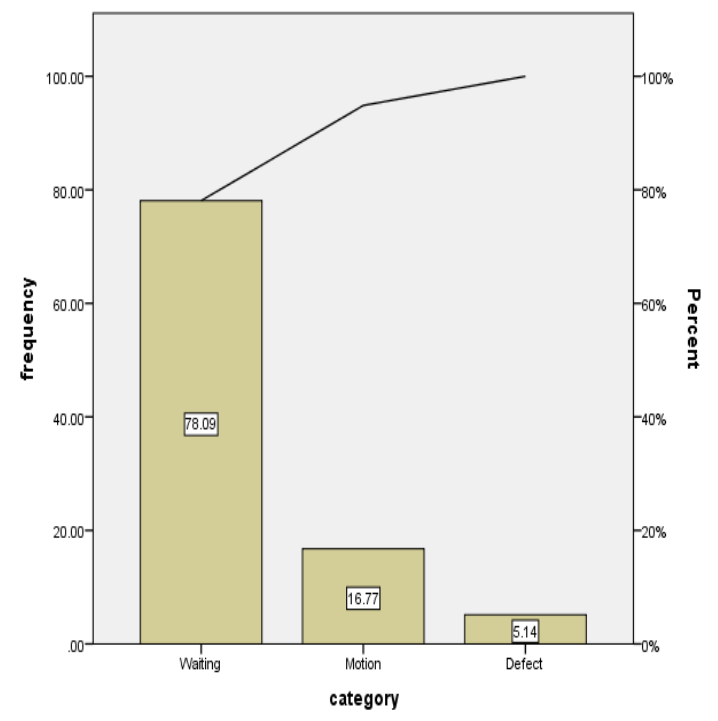

Gambar 2.Diagram Pareto

\section{Akar Penyebab Waste}

Berdasarkan hasil dari identifikasi waste yang telah dilakukan pada tahap sebelumnya, waste terbesar adalah waste waiting dengan persentase kejadian sebesar 78,09\%. Selanjutnya dilakukan identifikasi akar-akar penyebab masalah dengan menggunakan bantuan tools fishbone diagram.Penentukan akar penyebab yang akan ditampilkan dalam fishbone diagram dilakukan berdasarkan faktor material, method, man, machine, dan environment. Sedangkan untuk mendukung ketelitian akar penyebab dari kelima faktor di atas, dilakuakan analisis 5 whys.

\section{Usulan Perbaikan}

\section{Lean Tools}

1. Perbaikan Alur Proses Filling

Perubahan alur proses filling ini dilakukan dengan memindahkan operasi labelling setelah operasi capping. Berdasarkan pengamatan yang telah dilakukan pemindahan pada operasi labelling ini yang paling memungkinkan dilakukan karena proses labelling tidak akan menjadi masalah jika dilakukan setelah operasi capping. Tujuan dari dilakukannya perbaikan ini adalah untuk meminimalkan terjadinya defect mengingat penyebab terbesar terjadinya defect adalah etiket basah.

Perubahan lainnya yang memungkinkan untuk dilakukan adalah memindahkan satu operator pada operasi pertama yaitu persiapan jerigen ke operasi labelling. Jika pemindahan operator ini diterapkan, maka estimasi waktu yang dibutuhkan untuk lamanya operasi persiapan jerigen adalah dua kali lebih lama dari keadaan saat ini yaitu menjadi 30.16 detik/batch.Sedangkan operasi labelling menjadi dua kali lebih cepat karena dikerjakan oleh dua orang operator, yaitu menjadi $37,40 \mathrm{detik} / \mathrm{batch}$.

2. Menghilangkan Operasi Kerja Plugging Menghilangkan operasi kerja pada proses filling ini dilakukan pada operasi keempat, yaiu capping dalam atau operasi plugging. Hal ini dilakukan untuk mengurangi total operation time yang terjadi. Operation time pada operasi capping dalam dan capping luar secara berturut-turut adalah sebesar 11,80 detik/batch dan 42,01 detik/batch.Jika improvement ini dilakukan, maka estimasi waktu yang dibutuhkan untuk melakukan operasi capping ini adalah sama dengan operasi capping luar yaitu sebesar 42,01 detik/batch.

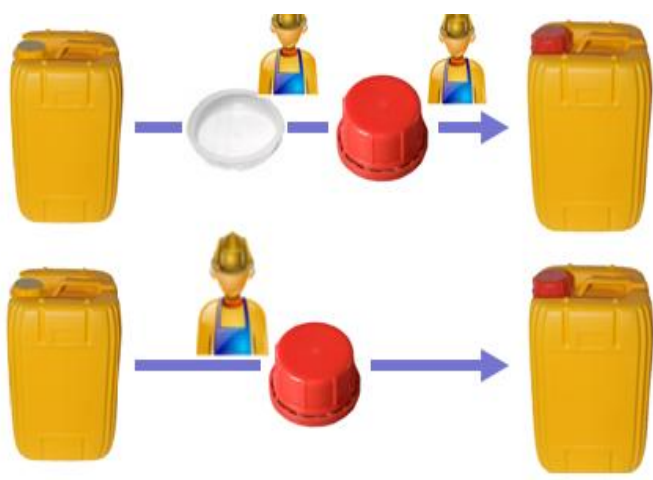

Gambar 3.Improvement Cap

Dari hasil perubahan yang telah dilakukan makadapat dibuat detail waktu dari masingmasing operasi berdasarkan improvement yang akan dilakukan.

Tabel 3.Operation Cycle Time

\begin{tabular}{ccc}
\hline $\begin{array}{c}\text { Operasi } \\
\text { ke- }\end{array}$ & Nama Operasi & $\begin{array}{c}\text { Operation Cycle } \\
\text { Time }\end{array}$ \\
\hline 1 & Persiapan & $30,16 \mathrm{detik} / \mathrm{batch}$ \\
2 & Jerigen & $59,04 \mathrm{detik} / \mathrm{batch}$ \\
3 & Filling & $42,01 \mathrm{detik} / \mathrm{batch}$ \\
4 & Capping & $37,40 \mathrm{detik} / \mathrm{batch}$ \\
5 & Labelling & $11,75 \mathrm{detik} / \mathrm{batch}$ \\
6 & Timbang & $8,19 \mathrm{detik} / \mathrm{batch}$ \\
\hline \multicolumn{2}{c}{ Total Operation Time } & $188,55 \mathrm{detik} / \mathrm{batch}$ \\
\hline
\end{tabular}

\section{Line Balancing}

Metode line balancing yang akan digunakan dalam improvement ini adalah metode Killbridewester. Penggunaan metode ini bertujuan untuk 
menekan waktu menganggur seminimal mungkin dengan membagi tugas dalam stasiun kerja.

Cycle Time $=59,04$ detik

Penentuan Stasiun Kerja dengan Metode Killbride-wester.

Tabel 4. Line Balancing Details

\begin{tabular}{cccccc}
\hline SK & OP & OCT & $\begin{array}{c}\text { Jumlah } \\
\text { OCT }\end{array}$ & CT & $\begin{array}{c}\text { CT- } \\
\text { OCT }\end{array}$ \\
\hline 1 & 1 & 30,16 & 30,16 & 59,04 & 28,88 \\
2 & 2 & 59,04 & 59,04 & 59,04 & 0 \\
3 & 3 & 42,01 & 42,01 & 59,04 & 17,03 \\
& 4 & 37,40 & & & \\
4 & 5 & 11,75 & 57,34 & 59,04 & 1,7 \\
& 6 & 8,19 & & & \\
\hline
\end{tabular}

Total Waktu 188,55

Delay Time $(\mathrm{DT})=28,88+15,33$ $=44,20$ detik

Persentase Delay Time (\% DT)

$=\frac{D T}{O C T} \times 100 \%$

$=\frac{44,20}{18855} \times 100 \%$

$=23 \%$

Efisiensi Lintasan (LE)

$=\frac{\sum O C T}{S K . C T} \times 100 \%$

$=\frac{18955}{4 \times 59,04} \times 100 \%$

$=79,83 \%$

Smoothness Index (SI)

$=\sqrt{\sum(C T-O C T)^{2}}$

$=\sqrt{\sum(28,88+0+17,03+1,7)^{2}}$

$=33$

Persentase delay time yang didapat jika usulan ini diterapkan adalah sebesar $20 \%$. Hal ini berarti mengalami penurunan delay time dari 57\% menjadi 20\%. Selain itu, efisiensi lintasan mengalami kenaikan dari $42 \%$ menjadi $79,83 \%$. Perbaikan yang dilakukan dengan penerapan line balancing ini cukup signifikan untuk meningkatkan produktvitas di filling plant.
4. Redesain Layout

Berdasarkan hasil line balancing, redesain layout ditunjukkan pada gambar 4.12 masing-masing operasi ditempatkan pada stasiun kerja yang telah dibuat berdasarkan hasil line balancing. Penerapan dari line balancing ini dapat menunjukkan continuous flow dari proses filling. Selain itu, dapat meminimalkan waiting akibat penumpukan WIP antar operasi kerja. Persentase delay time juga dapat dikurangi hingga mencapai angka 20\%. Waste defect juga mengalami penurunan dengan perbaikan alur proses filling jika improvement ini diterapkan.

\section{VSM: Future State Map}

Tahap selanjutnya setelah usulan improvement dibuat adalah merancang future state map yang mendukung perbaikan yang diusulkan sesuai dengan konsep lean manufacturing. Dengan penerapan lean ini diestimasikan output yang dihasilkan dapat memenuhi demand konsumen saat ini yaitu sebesar 6000 unit/hari. Hasil future stae map dapat dilihat pada Lampiran 2.

Pembuatan future state value stream mapping ini didasarkan pada current state dan hasil rekomendasi yang akan diberikan.Beberapa rekomendasi yang diusulkan adalah perbaikan alur proses filling, penggabungan operasi kerja, penerapan line balancing, dan redesain layout pada filling plant. Rekomendasi perbaikan yang diusulkan berdasarkan hasil pengamatan diskusi dengan bagian filling plant. Selain itu, perubahan yang dilakukan juga berdasarkan pada kemungkinan yang bisa dilakukan tanpa menggangu proses filling berlangsung. Perubahan yang terjadi jika menerapkan rekomendasi yang diberikan terseut, antara lain:

1. Menurunnya total operation cycle time sehingga output dan kapasitas produksi meningkat dan dapat memenuhi demand konsumen.

2. Mengurangi tingkat produk defect akibat etikat basah yang sering terjadi selama proses filling.

3. Mengurangi jumlah penumpukan WIP antaroperasi karena terjadi penyeimbangan lini dengan line balancing sehingga menekan persentase delay time menjadi $20 \%$.

4. Mengurangi jumlah operator dari tujuh orang menjadi 6 orang

5. Meningkatkan efisiensi lini dari $42 \%$ menjadi $79,83 \%$. 


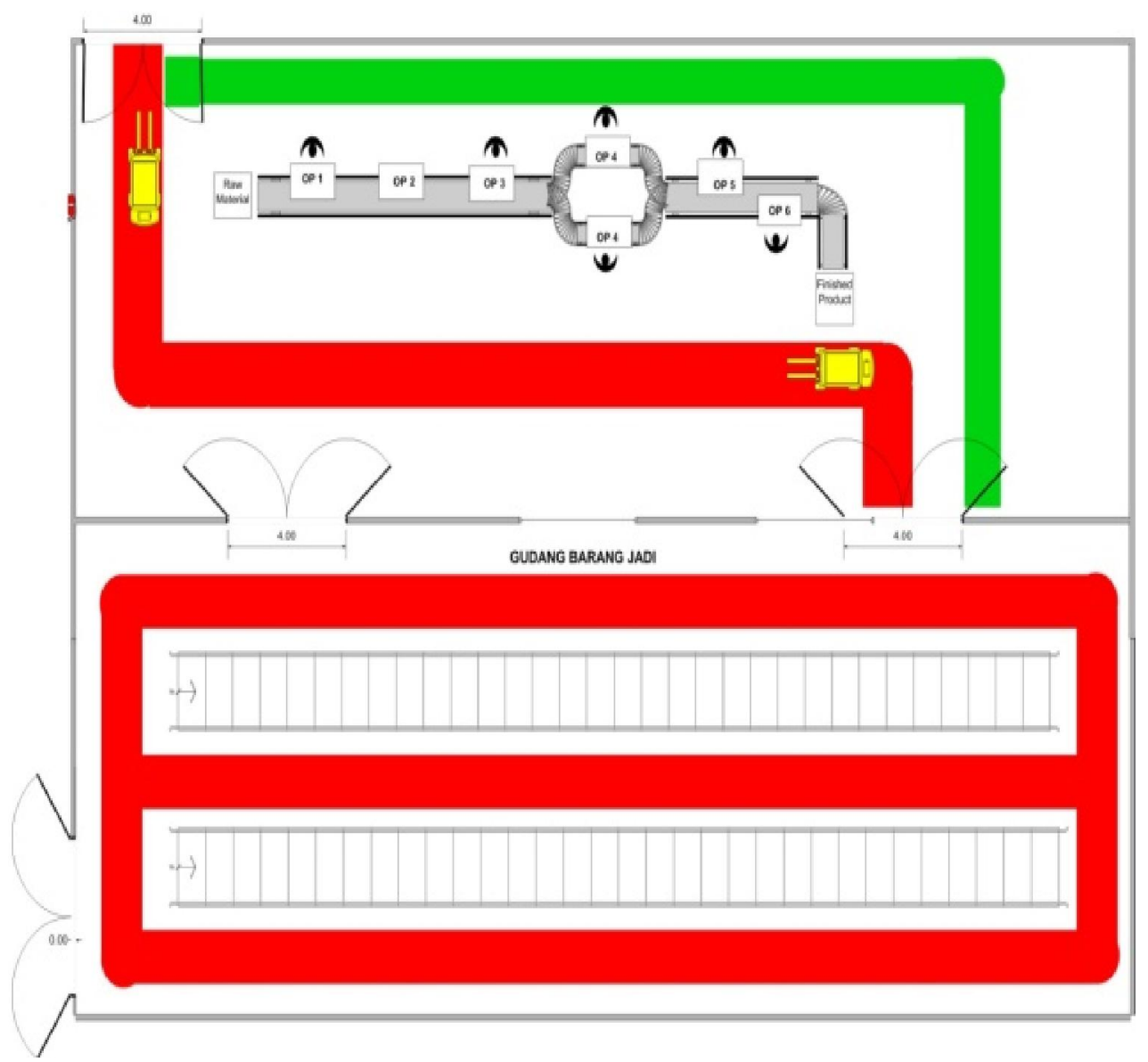

Gambar 4. Redesign Layout

Tabel 5. Perbandingan Sebelum dan Setelah Lean

\begin{tabular}{|c|c|c|c|}
\hline NO & Keterangan & $\begin{array}{c}\text { Sebelum } \\
\text { Lean }\end{array}$ & Setelah Lean \\
\hline 1 & $\begin{array}{ll}\text { Waiting } & \\
-\quad \% & \text { Delay } \\
\text { Time } & \end{array}$ & $\begin{array}{l}\text { Total WIP = } \\
3279 \text { unit } \\
-57 \%\end{array}$ & $\begin{array}{l}\text { Total WIP }=650 \\
\text { unit } \\
-23 \%\end{array}$ \\
\hline 2 & Jumlah SK & $7 \mathrm{SK}$ & $4 \mathrm{SK}$ \\
\hline 3 & $\begin{array}{l}\text { Jumlah } \\
\text { Operator }\end{array}$ & 7 Orang & 6 Orang \\
\hline 4 & $\begin{array}{l}\text { Defect (Saving } \\
40 \% \text { ) }\end{array}$ & 216 unit & 129 unit \\
\hline 5 & Cycle time & $\begin{array}{l}74,79 \\
\text { detik/batch }\end{array}$ & $59,04 \mathrm{detik} / \mathrm{batch}$ \\
\hline 6 & $\begin{array}{l}\text { Total } \\
\text { Operation Time }\end{array}$ & $\begin{array}{l}\text { 222,66 } \\
\text { detik/batch }\end{array}$ & $\begin{array}{l}\text { 188,55 } \\
\text { detik/batch }\end{array}$ \\
\hline 7 & Productivity & 0,61 & 0,85 \\
\hline 8 & $\begin{array}{l}\text { Efisiensi Lini } \\
\text { (LE) }\end{array}$ & $42 \%$ & $79,83 \%$ \\
\hline
\end{tabular}

Pada tabel 5 adalah hasil perbandingan keadaan proses filling sebelum dan setelah diterapkannya lean.

\section{Kesimpulan}

Hasil identifikasi pemborosan atau waste pada proses filling dengan menggunakan value stream Jurnal Teknik Industri, Vol. X, No. 2, Mei 2015 mapping didapatkan tiga waste yaitu waitingselama 11,24detik/batch, unnecessary motion sebesar 10,05 detik/batch, dan defect sebesar 4,4\%.

Pemborosan paling utama adalah waste waiting. Faktor yang menyebabkan waiting adalah jumlah penumpukan jerigen antaroperasi karena adanya perbedaan waktu operasi yang cukup 



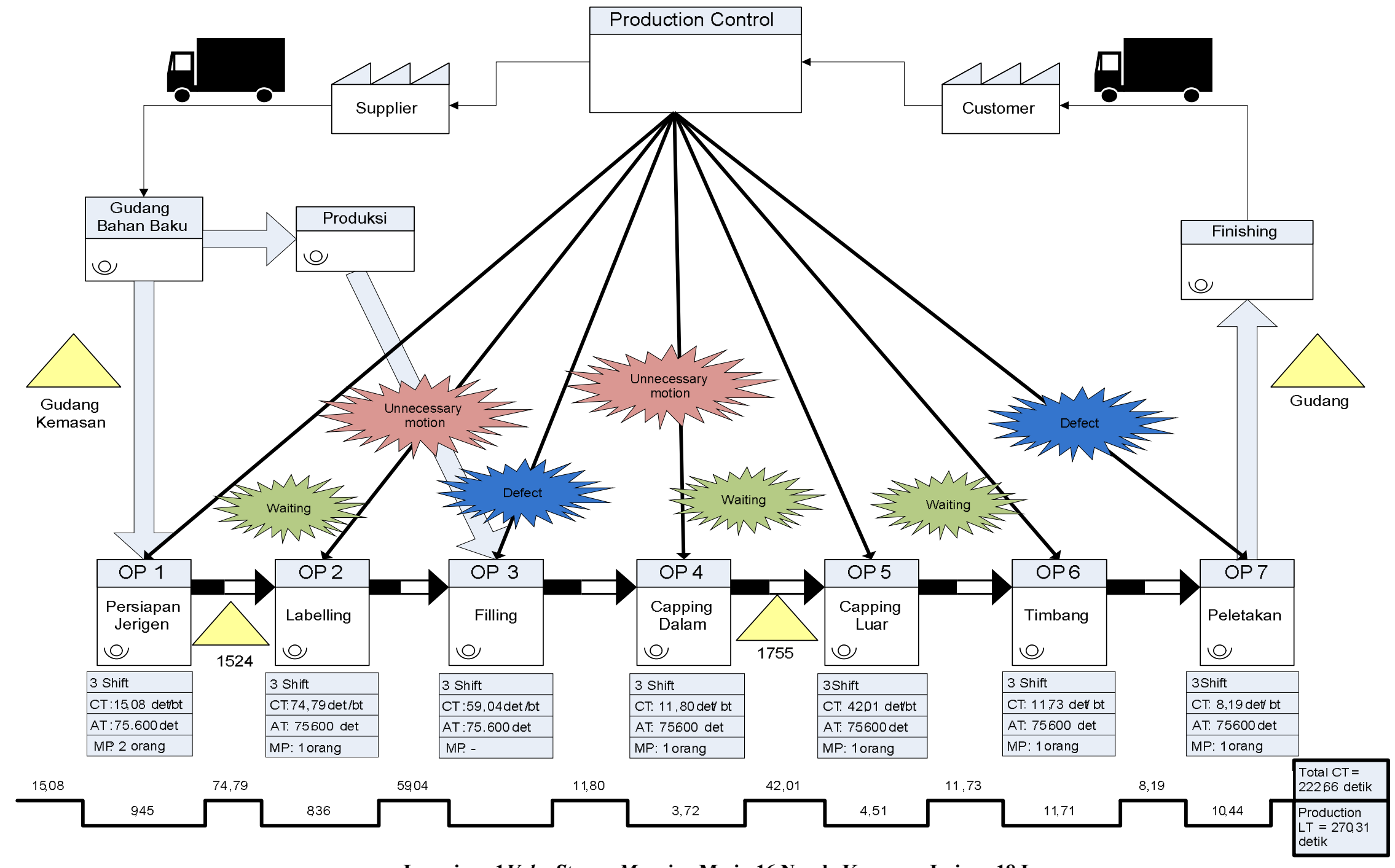

Lampiran 1 ValueStream Mapping Mesin 16 Nozzle Kemasan Jerigen 18 L 


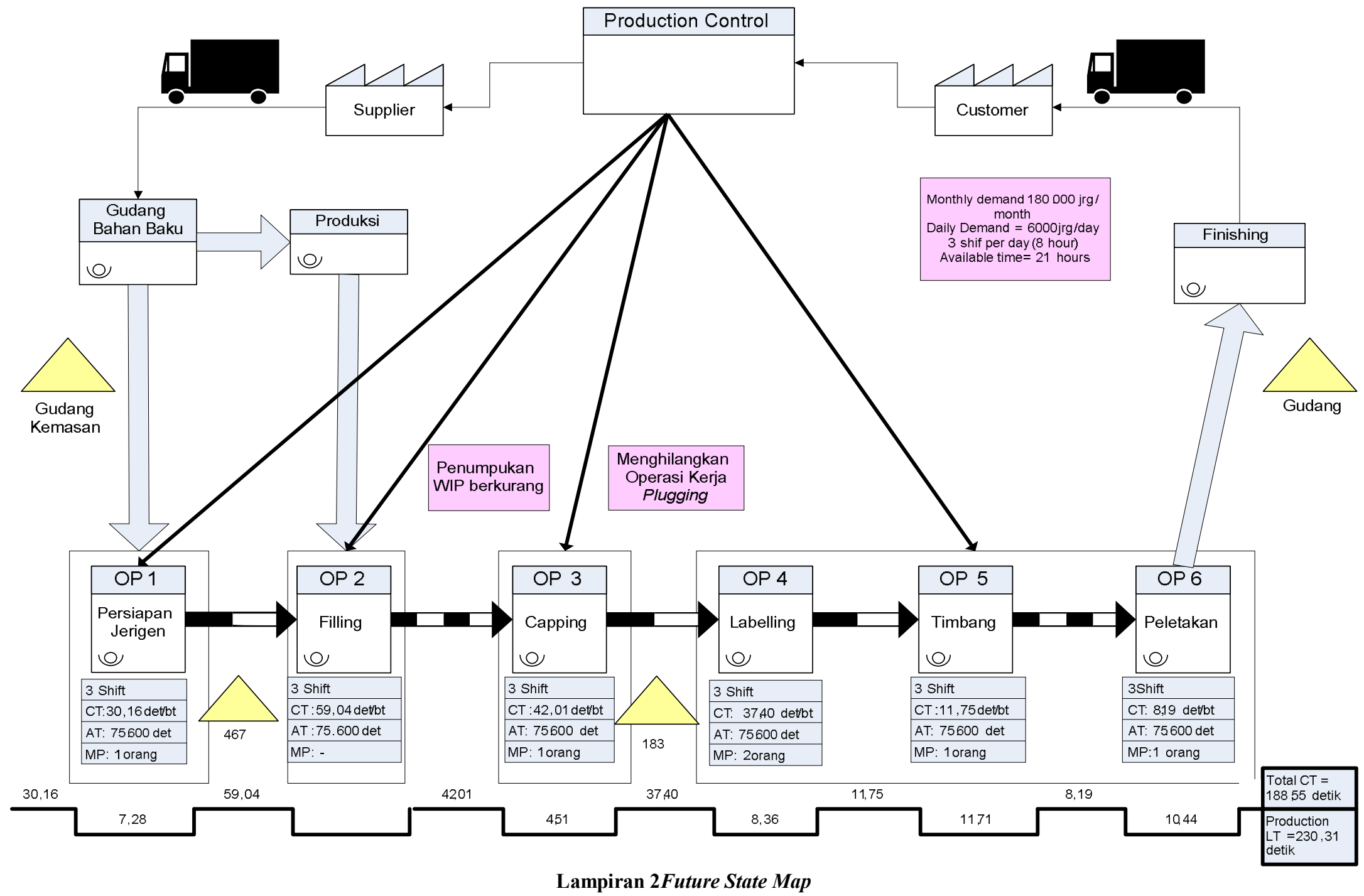

